\title{
Implicações imperiais ligadas ao Codex Purpureus Rossanensis ( $\Sigma$ 042): Apontamentos a partir de uma análise imagética
}

\section{Karolina Santos da Rocha *}

DOI: 10.11606/issn.2318-8855.v9i1p318-348

Resumo: O Codex Purpureus Rossanensis ( $\Sigma$ 042) foi constantemente analisado a partir de um viés ocidental e moderno, o que afetou diretamente o sentido desse documento histórico. Assim, este artigo se propõe a entender a especificidade do pensamento figurativo e da composição textual bizantina a partir de problemáticas relativas ao seu possível contexto e espaço de produção. Concentramo-nos na análise de 3 fólios específicos, particularmente relevantes. Acreditamos que há uma dinâmica significativa e que se diferencia das outras figurações no que diz respeito à repetição de conteúdo. Concentramos nossa atenção nos temas eucarísticos que estão presentes em três fólios: A Última Ceia (fol. 3r); a distribuição do pão (fol. 3v) e a distribuição do vinho (fol. 4r). Discordamos, porém, da historiografia tradicional que discute o tema, na medida em que essa sequência de imagens ultrapassa aspectos religiosos e remete a implicações imperiais e rituais da corte bizantina.

Palavras-chaves: Iconografia bizantina; manuscritos neo-testamentários; representações eucarísticas.

* Graduanda em História pela Universidade Estadual de Montes Claros (Unimontes). Contato: karolina.ssantos@yahoo.com. 


\section{artigos}

\section{Implicações imperiais ligadas ao Codex Purpureus Rossanensis ( $\Sigma 042)$ :}

Apontamentos a partir de uma análise imagética

\section{Introdução ${ }^{1}$}

Publicado na Itália em 1846, La Toscana: I'Umbria e la Magna Grecia é um dos principais livros de viagens do escritor capuano Cesare Malpica, pois contém a mais antiga menção ${ }^{2}$ ao Codex Purpureus Rossanensis ( $\left.\begin{array}{ll}\Sigma & 042\end{array}\right)^{3}$. O objeto teria sido encontrado no meio de arquivos empoeirados e negligenciados da sacristia da Cattedrale di Maria Santissima Achiropita em Rossano, e continuou sendo pouco conhecido até 1880, quando Oscar von Gebhardt publicou a primeira descrição do códice juntamente com a transcrição de seu texto (GEBHARDT, 1880). A partir de então, o Codex Purpureus Rossanensis passou a ser cada vez mais valorizado, tanto por sua importância para a reconstituição do texto dos evangelhos de Mateus e Marcos quanto por sua rica ornamentação, que inclui a redação do texto em caracteres dourados e prateados e a reprodução de 14 fólios iniciais com imagens.

Há, sobretudo, um desempenho considerável realizado não só por parte da cidade de Rossano, mas também por toda a Calábria em construir a sua memória regional a partir da vinculação com o codex. Essa, por sua vez, não se limita ao campo religioso e se insere no espaço político, como se pode verificar, por exemplo, na inauguração de um monumento inspirado no manuscrito - conhecido como la

\footnotetext{
${ }^{1}$ Agradeço ao meu orientador, prof. Dr. Vinicius Cesar Dreger de Araujo; e ao prof. Dr. Robson Murilo Grando Della Torre, pela transcrição e tradução dos fólios e pela leitura crítica deste artigo.

2 "Il capitolo del Duomo possiede un tesoro in un libro antichissimo che contiene gli Evangeli scritti in Greco, con caratteri d'argento sovra carta azzurrina, con belle e curiose miniature in testa alla pagine." "O capítulo catedralício possui como tesouro um livro antiquíssimo que contém os Evangelhos escritos em grego, com caracteres prateados em papel azulado, com belas e curiosas miniaturas no topo das páginas." (MALPICA, 1846, p. 333, tradução nossa).

${ }^{3}$ O manuscrito é reconhecido pela indicação alfanumérica $(\Sigma 042)$ referente ao sistema Gregory Aland e (LDBA 2990) à Leuven Database of Ancient Books. Neste artigo, utilizamos a referência mais utilizada: $\Sigma$ 042.
} 


\section{artigos}

Karolina Santos da Rocha

macchina armonica -, erigido em uma importante via de acesso a Rossano no ano de 2015. O evento contou com a presença do arcebispo da diocese, dom Giuseppe Satriano, e do prefeito Giuseppe Antoniotti. Nas palavras do político:

De fato, estamos convencidos de que dar destaque e identificar a cidade de Rossano com seu monumento mais precioso poderá impulsionar, no futuro próximo, um maior desenvolvimento econômico-turístico (...). Para promover e saber vender essa riqueza inestimável ao turismo de massa, precisamos, antes de tudo, que nós mesmos a conheçamos e a apreciemos. É um caminho longo que parte das escolas, onde, durante o último ano letivo, concluímos, graças à preciosa colaboração dos professores e diretores, alguns projetos voltados precisamente para instruir os jovens sobre a importância e singularidade do Códice. Além disso, substituímos todos os sinais de trânsito, caracterizando-os pela marca Città del Codex. Basicamente, estamos colocando em prática todas as inspirações, ideias e programas resultantes do fórum-debate realizado no último verão e promovido pelo vereador Lorenzo Antonelli, que dedica muito tempo, ideias e energia de sua atividade institucional à promoção deste nosso monumento de identidade (...). [La macchina armonica é] um monumento que se refere precisamente à nossa identidade e, obviamente, ao Codex Purpureus Rossanensis. ${ }^{4}$

Há, evidentemente, um esforço de manipulação de uma fonte histórica em função de exigências do presente no âmbito da vida política, econômica e social, que é alcançado, sobretudo, com a construção de um sentimento de pertencimento a um símbolo específico, neste caso: o codex. Ademais, isso mostra um panorama interessante para a compreensão de um gradual processo de substituição de aspectos religiosos para elementos pátrios, indicando uma ressignificação do material ao longo dos séculos.

É fácil perceber, então, como essa abordagem também se insere no campo historiográfico. Tendo em vista o local em que foi descoberto, alguns estudiosos ${ }^{5}$ reconheceram o manuscrito como um produto de casas monásticas do Mezzogiorno.

4 Discurso disponível em: https://www.lameziaoggi.it/cosenza/2015/07/25/rossano-inauguratomonumento-ispirato-codice-purpureo/, acesso em: 05/03/2020.

5 Tais como: GRADMANN, 1896; BEISSEL, 1893; STUHLFANTH, 1897. 


\section{Implicações imperiais ligadas ao Codex Purpureus Rossanensis ( $\Sigma 042)$ :} Apontamentos a partir de uma análise imagética

Esta hipótese já está bastante criticada, pois o códice apresenta uma composição e um estilo claramente oriental e não havia exemplos no ocidente na época ${ }^{6}$, como veremos mais adiante.

Certamente foi preciso, conforme esta linha de consideração, delinear uma nova tese acerca do documento. A hipótese defendida por Gennaro Mercogliano é um bom exemplo disso. Segundo ele, Teofano, esposa de Oto II e descente da família imperial bizantina, teria doado o Codex Purpureus Rossanensis diretamente ao bispo de Rossano no século X. Nas palavras dele: “Mesmo na ausência de prova objetiva, é plausível apresentar a hipótese e pensar que a Imperatriz Teofano foi quem levou o codex a Rossano, a quem a cidade deve por essa eterna gratidão" (MERCOGLIANO, 2016, p. 90) ${ }^{7}$. A hipótese nos parece bastante improvável, pois, embora os Regesten Sächsisches Haus $^{8}$ indiquem que o casal esteve em Rossano em 982 durante as batalhas em Cotrone, não existem evidências que, minimamente, suportem a hipótese da chegada do Rossanensis ao ocidente neste momento. Dessa forma, compreendemos que esse discurso é apresentado como uma tentativa de construir

\footnotetext{
${ }^{6}$ Isso não impediu, no entanto, que a maior parte dos pesquisadores que se dedicaram ao estudo do Codex Purpureus Rossanensis relacionassem o conteúdo do manuscrito - principalmente suas imagens às produções ocidentais produzidas no período medieval no Sul da Itália, como é o caso dos afrescos de influência bizantina em Sant'Angelo in Formis na cidade de Cápua, datado entre 1072 e 1087 (ver GRADMANN, 1896).

${ }^{7}$ Apesar da hipótese ter sido apresentada como uma interpretação original em seu livro L'imperatrice Teofano e il Codex, ela foi primeiro proposta por Fillippo Burgarella em um debate realizado em Rossano no ano de 2014. Na ocasião, o manuscrito não se encontrava na cidade, pois tinha sido submetido a um longo processo de restauração em Roma, de modo que a hipótese foi interpretada como um apelo a devolução do livro a Rossano.

${ }^{8}$ Ver BÖHMER, Johann F. Regesta Imperii II. Sächsisches Haus: 919-1024. Dritte Abteilung: Die Regesten des Kaiserreiches unter Otto III. Nach Johann Friedrich Böhmer neuarbeitet von Mathilde Uhlirz. Graz; Köln: Böhlau, 1956, p. 416 (956g). Disponível em: https://daten.digitalesammlungen.de/bsb00009238/images/index.html?id=00009238\&groesser=\&fip=eayaqrsxsfsdrxdsydxd syden $x$ dsydsdas \&no=10\&seite $=6$. Acesso em: 07/03/2020.
} 


\section{artigos}

\section{Karolina Santos da Rocha}

um itinerário coerente e ilustre para o codex, o que legitima o local de pertencimento atual do manuscrito, mas que se encontra imbuído de lacunas e inexatidões.

Isso indica os riscos de se interpretar uma fonte bizantina do século VI por um viés ocidental e moderno, o que afeta diretamente o sentido desse documento histórico. Como vimos, a identidade do codex e o seu significado são, geralmente, pensados a partir do momento em que foi transladado para a Itália meridional, assim como o seu conteúdo imagético é comparado frequentemente com produções ocidentais. Faltam, portanto, pesquisas que se dediquem ao estudo dos modos de operação e funcionamento das imagens e dos textos que compõem o manuscrito.

Assim, este artigo se propõe a entender a especificidade do pensamento figurativo e da composição textual bizantina a partir do Codex Purpureus Rossanensis pensando em problemáticas relativas ao seu possível contexto e espaço de produção. Iremos nos concentrar em 3 fólios específicos, particularmente relevantes, pois apresentam uma dinâmica significativa se comparados as outras figurações do manuscrito. No entanto, não se trata de propor uma substituição completa da historiografia, mas sim de revisar e redirecionar as formas e os objetivos pelos quais o manuscrito foi analisado.

\section{O Codex Purpureus Rossanensis ( $\Sigma$ 042)}

Como vimos, o manuscrito $\Sigma 042$ se encontra atualmente no Museo Diocesano e del Codex na cidade de Rossano, na região da Calábria (Sul da Itália). Trata-se de uma cópia de luxo dos evangelhos incompletos produzidos no século VI e compõe uma família de três manuscritos: Codex Purpureus Petropolitanus (N 022), Codex Purpureus 


\section{artigos}

\section{Implicações imperiais ligadas ao Codex Purpureus Rossanensis ( $\Sigma 042)$ :} Apontamentos a partir de uma análise imagética

Sinopensis (O 023) e o nosso objeto de análise, o Codex Purpureus Rossanensis ( $\Sigma$ 042). ${ }^{9}$ Este possui 188 fólios em pergaminho purpúreo, medindo 25,0 x 30,0 (cm). Seus caracteres são escritos em letra uncial nas cores dourada (com posicionamento padrão nas três primeiras linhas de cada página de texto), prateada (restante do texto) e preta (nas inscrições relacionadas às miniaturas). ${ }^{10} \mathrm{O}$ conteúdo textual do manuscrito está em grego e contém o texto completo do evangelho de Mateus, o texto incompleto do evangelho de Marcos, 40 trechos do Antigo Testamento e o início da epístola de Eusébio de Cesaréia a Carpiano, que disserta sobre as origens do sistema de tabelas canônicas e dá instruções sucintas para seu uso ${ }^{11}$. Além disso, o codex possui quinze fólios com imagens, dos quais doze representam o ciclo da vida de Cristo.

Em relação ao local de produção do codex, trata-se de um debate bastante controverso. Muitos estudiosos apontam diversas localidades específicas. Guglielmo Cavallo (1992) defende que o manuscrito tenha sido produzido no ambiente SírioAntioqueno ou na Palestina com base em uma análise paleográfica do texto. Da

\footnotetext{
${ }^{9}$ Não apenas a aparência e o procedimento técnico foram usados para estabelecer essa relação entre os códices, mas, principalmente, o conteúdo textual. O que não exclui a possibilidade de encontrar semelhanças com o Vienna Genesis, por exemplo.

10 Segundo GEBHARDT (1880), a tinta preta parece pertencer aos séculos XVII ou XVIII, assim como a encadernação atual do manuscrito.

11 Para facilitar o estudo dos Evangelhos, Eusébio dividiu os textos em capítulos e começou a traçar paralelos entre eles para mostrar quais passagens eram tratadas por dois ou mais evangelistas e quais eram exclusivas de determinado autor. Dessa forma, ele criou uma tabela de equivalência que funcionava da seguinte maneira A - a passagem se apresenta nos quatro evangelhos; B - a passagem se apresenta em Mateus, Marcos e Lucas; $\Gamma$ (gamma) - a passagem se apresenta em Mateus, Marcos e João; $\Delta$ - a passagem se apresenta em Mateus, Lucas e João; e assim por diante até I - a passagem é exclusiva do autor em questão. A dita "tabela canônica" de Eusébio é essencialmente a listagem desses dez índices, enquanto a carta a Carpiano explica como usá-la.
} 


\section{artigos}

Karolina Santos da Rocha

mesma maneira, William Loerke (1987) reconhece a Síria como local de produção do objeto a partir de algumas características das miniaturas. Sabemos, no entanto, que muitas dessas características aparecem fora na Síria. Kurt Weitzmann (1977) encontra conexões com Jerusalém, que são sugeridas através das miniaturas de Pilatos e da Comunhão dos apóstolos contidas no $\Sigma$ 042. Segundo ele, tratam-se de representações comuns naquela região. Além disso, há autores que defendem Constantinopla como o local de produção de diversos códices púrpuras devido a sua associação com a cultura imperial. Para Elijah Hixson (2019), é possível que o manuscrito tenha sido produzido no ambiente multicultural em Constantinopla durante ou logo após o reinado de Justiniano I (527-565) como um presente para alguma das igrejas por ele construídas.

Observemos que é possível encontrar diversas relações entre o codex e muitas regiões orientais. Porém, o reconhecimento do local de produção do objeto deve ser apresentado como uma hipótese, pois falta a documentação necessária para a sua efetiva conclusão, sendo feita através da comparação de qualidades estilísticas e técnicas em outros manuscritos do período. Nesse sentido, acrescentamos que "seria inútil tentar escrever uma história estilística coerente da iluminação de livros da Antiguidade Tardia e dos primeiros cristãos, já que tudo o que resta é comparável a algumas ilhas de um oceano que se estende além do que os olhos podem ver" (WEITZMANN, 1977, p. 21).

Mas como, quando e por que o manuscrito $\Sigma 042$ teria sido transladado para o Ocidente? Durante muito tempo, a historiografia tradicional entendeu que o processo de bizantinização da Itália meridional se deu a partir da emigração de monges gregos expulsos do Oriente por perseguição iconoclasta durante o século VIII. O translado do Codex Rossanensis também foi pensado por esse viés, de modo que a maioria dos 


\section{artigos}

\section{Implicações imperiais ligadas ao Codex Purpureus Rossanensis ( $\Sigma$ 042):}

Apontamentos a partir de uma análise imagética

autores concordam com essa tese. Para Antonio Muñoz (1907), por exemplo, "o Codex Purpureus Rossanensis pertence à arte monástica. E essa origem explica bem como ele chegou ao sul da Itália: transportado por basilianos, que, em Rossano, tinham um próspero centro de atividade" (MUÑOZ, 1907, p. 27). Ademais, foi apresentada a possibilidade de o objeto ter sido submetido as múltiplas relações comerciais entre o Mezzogiorno e a Síria no início do século VII. Isso parece bastante improvável, devido a sua rica proveniência e o seu significado religioso.

Há, entretanto, outras interpretações. A partir do estudo de Pierre Batiffol (1891), percebemos que o Codex pode ter sido transladado durante o século XI para o monastério de Rossano (atual Abbazia di Santa Maria del Patire), fundada em 1095 por Bartolomeu de Sumeri. Segundo Pierre Batiffol, todo o acervo inicial do mosteiro de Rossano foi trazido de Constantinopla por Bartolomeu de Sumeri por volta do ano 1100. Bartolomeu era um monge local que, devido a sua aproximação com o rei Roger II, recebe recursos reais para fazer a viagem até Constantinopla ${ }^{12}$ a fim de buscar um instrumental suficiente para montar um mosteiro de rito grego em Rossano. No pacote trazido do Oriente, havia diversos objetos, tais como: material litúrgico, paramentos, objetos de devoção e alguns livros. Um deles se encaixa nas características que o Codex Purpureus Rossanensis oferece. Contudo, é importante enfatizar que Batiffol não confirma que o manuscrito chegou ao Ocidente a partir desse pacote. Essa é uma hipótese que estamos desenvolvendo a partir das sugestões dele.

\footnotetext{
${ }^{12}$ Isso poderia confirmar o possível local de produção do $\Sigma 042$ em Constantinopla.
} 


\section{artigos}

\section{Karolina Santos da Rocha}

Além da discussão sobre a origem e translatio da fonte, muitos pesquisadores debateram a respeito da ordem dos fólios que compõem o manuscrito. Trata-se de um argumento de base iconográfica que garante que a sequência e a ordem das imagens estejam equivocadas e fora de seu arranjo original. Atualmente, a ordem sequencial dos fólios presentes no codex é a seguinte: Ressureição de Lázaro (Fol. 1r); entrada de Cristo em Jerusalém (Fol. 1v); expulsão dos vendedores no Templo (Fol. 2r); parábola das virgens (Fol. 2v); Santa Ceia e lavagem dos pés (Fol. 3r); distribuição do pão (Fol. 3v); distribuição do vinho (Fol 4r); oração de Cristo em Getsêmani (Fol. 4v); círculo ornamentado em medalhões com o busto dos quatro evangelistas (Fol. 5r); é deixado vazio (Fol. 5v); idem (Fol. 6r); Epistula ad Carpianum (Fol. 6v), cura do cego (Fol. 7r); parábola do Bom Samaritano (Fol. 7v); apresentação de Cristo diante de Pilatos e a traição e morte de Judas (Fol. 8r); visão geral do capítulo de Mateus (Fols. 9r-v) texto do Evangelho de Mateus (Fols. 10r-118v); visão geral do Evangelho de Marcos (Fol. 119r); é deixado vazio (Fol. 120r); figuração do evangelista Marcos (Fol. 121r); texto incompleto do Evangelho de Marcos (Fols. 122r-188v).

Segundo Haseloff (1898), na composição original do manuscrito havia cerca de 400 fólios, pois integrava também os Evangelhos de Lucas e João. Desse modo, além da perda dos textos e imagens das possíveis figuras dos 3 evangelistas, ele defende que o programa iconográfico original que consta no início do codex representaria toda a vida de Cristo e, por isso, estaria em uma ordem incorreta e incompleta. Loerke (1987), por outro lado, supõe que o livro trazia apenas os Evangelhos de Mateus e Marcos e que havia outro exemplar com os textos de Lucas e João. Nenhum deles, porém, compreende o sentido do arranjo iconográfico, caracterizando-o como desordenado e sem coerência. Gebhardt (1880), inclusive, propôs uma nova sequência para os fólios: Fol. 7; fol. 1; fol. 2; fol. 3; fol. 4 e fol. 8, como no esquema: 


\section{artigos}

Implicações imperiais ligadas ao Codex Purpureus Rossanensis ( $\Sigma 042)$ :

Apontamentos a partir de uma análise imagética

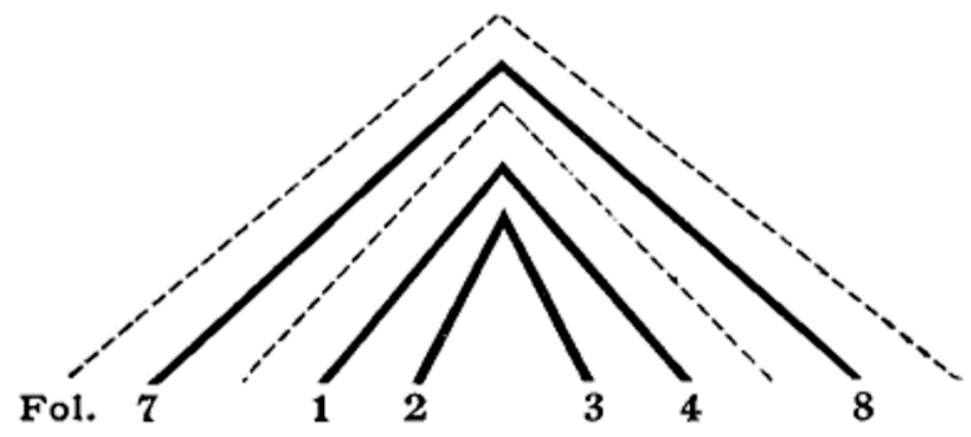

Figura 1: Esquema dos fólios construído por Arthur Haseloff, cf. (HASELOFF, 1898).

Essa abordagem compreende que a intenção das imagens no Rossanensis é seguir o padrão narrativo referente aos Evangelhos, o que não ocorre obrigatoriamente. Se comparado aos outros códices púrpuras, o ( $\Sigma$ 042) é o único em que as imagens são dispostas no começo, antecedendo o texto da escritura e, consequentemente, se distanciando da narrativa linear e coerente que caracteriza a construção textual. Essa escolha, portanto, poderia indicar uma seleção de episódios entendidos como mais importantes ou a organização de um arranjo original e específico. Além disso, notamos que as imagens que representam um determinado episódio não são construídas a partir de um único Evangelho, mas em cada uma delas há elementos extraídos dos vários textos ${ }^{13}$, o que mostra uma particularidade dessa organização figurativa capaz de se distanciar da narrativa cronológica e obter arranjos bastante originais.

Além do mais, mesmo que os fólios estejam incompletos, acreditamos que o programa inicial não era numeroso e não continha as cenas completas da vida de Cristo. Percebemos isso a partir do grande espaço que é deixado entre as miniaturas

\footnotetext{
${ }^{13}$ No fólio 3r, a Última Ceia (Mt 26, 17-30 e Mc 14, 12-26) é figurada juntamente com a Lavagem dos pés (Jo 13, 1-15).
} 


\section{artigos}

Karolina Santos da Rocha

e inscrições. Segundo Muñoz, não há economia de espaço - na verdade ele é frequentemente desperdiçado. Um claro exemplo é como Davi foi figurado 3 vezes lado a lado no fólio 3r. Isso indica, evidentemente, que foram realizadas escolhas de episódios a serem representados, já que cada fólio corresponde a um episódio bíblico.

Entretanto, essa consideração não se encaixa em três fólios utilizados para representar apenas um episódio bíblico: a Última Ceia. Trata-se de um tipo de figuração bastante detalhado e que ainda chamou pouca atenção dos estudiosos que se dedicam ao estudo do manuscrito ${ }^{14}$. Por outro lado, acreditamos que há uma dinâmica significativa e que se diferencia das outras figurações no que diz respeito à repetição de conteúdo, o que afeta a leitura visual e seletiva de quem observa. Nesse sentido, pretendemos analisar os modos de funcionamento e motivos iconográficos desses 3 fólios, seguido da argumentação e interpretação acerca do objeto de análise, que deve aqui ser entendido enquanto hipóteses.

\section{Análise dos fólios 3r, 3v e 4r}

A distribuição das miniaturas no Codex Purpureus Rossanensis, indica uma clara ênfase em temas eucarísticos, na medida em que este conteúdo está figurado em três fólios: A Última Ceia (fólio 3r); a distribuição do pão (fólio 3v) e a distribuição do vinho (fólio 4r). Contudo, apesar de caracterizar as cenas figuradas desta maneira, acreditamos que os três fólios em conjunto poderiam retratar a dita Santa Ceia, cada qual se concentrando em uma parte do evento (o primeiro fólio se divide em duas cenas: traição de Judas e lava-pés). E, como o documento se insere em um contexto eucarístico, os dois fólios seguintes apresentam o corpo e o sangue de Cristo que se

\footnotetext{
${ }^{14}$ Segundo Muñoz (1907, p. 20), “um estudo sobre essa representação, ainda não observado, seria de grande interesse".
} 


\section{artigos}

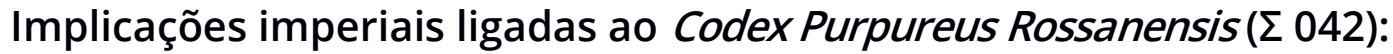
Apontamentos a partir de uma análise imagética

dá aos apóstolos (como inclusive está indicado nas citações dos Evangelhos que encabeçam cada fólio).
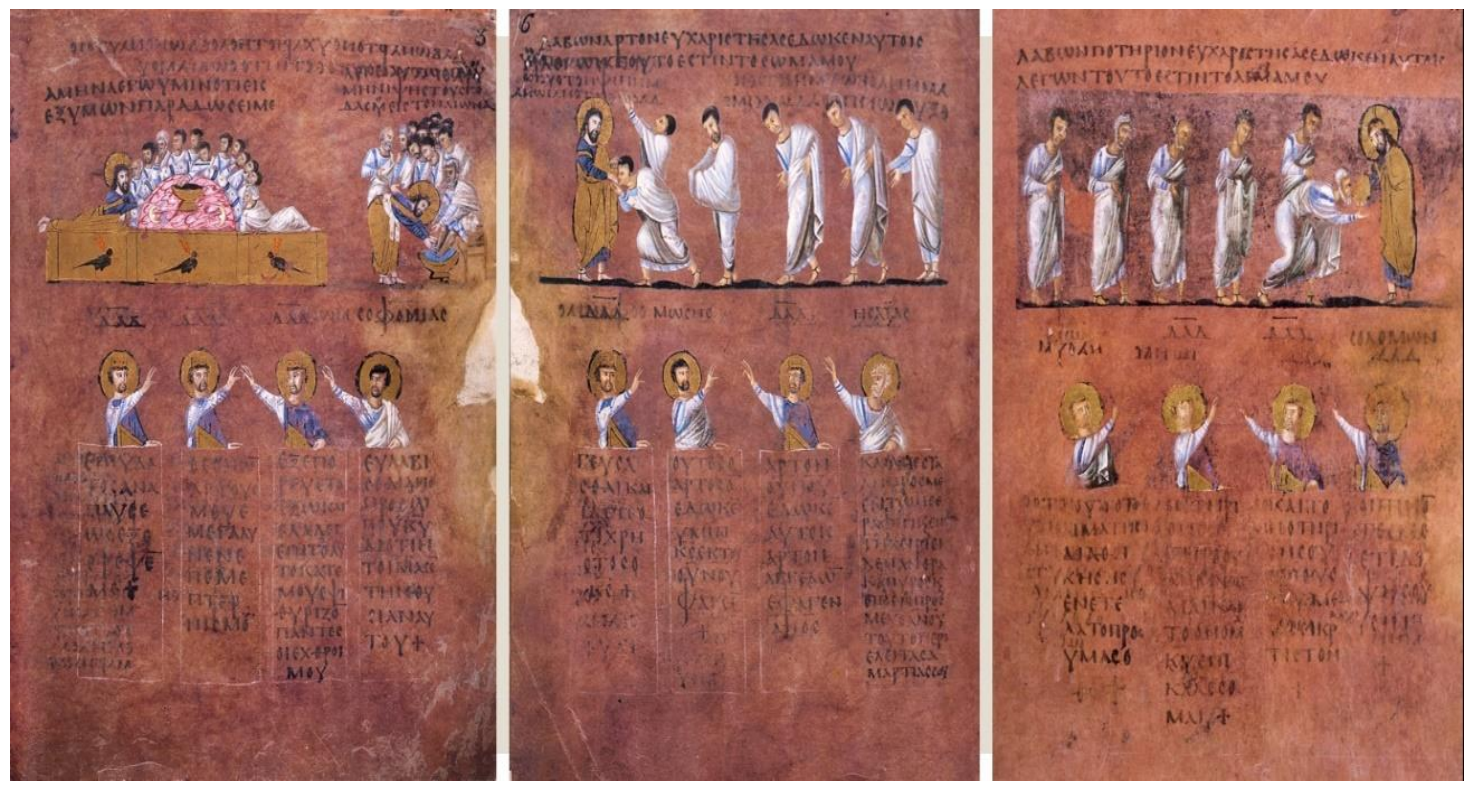


\section{artigos}

Karolina Santos da Rocha

Figura 2 - Respectivamente, fólios: 3r, 3v e 4r. Arcidiocesi di Rossano -Cariati (Unesco) ${ }^{15}$

Um dos arranjos cênicos mais famosos da iconografia do cristianismo foi inspirado pelas seguintes passagens neotestamentárias (Mt 26, 26-28; Mc 14, 22-25; Lc 22, 14-20; Jo 6, 48-56): trata-se do estabelecimento da Eucaristia, um dos principais rituais cristãos, como representação e representificação da assim chamada, Santa Ceia. Sabemos que a Eucaristia adquire significado não isoladamente, mas através de sua ação ritual, caracterizada por Hans Belting (1981) como a mais importante e mais frequentemente revivida e reatualizada a cada celebração, de modo que o rito eucarístico se torna o núcleo da linguagem litúrgica.

Tal perspectiva pode inserir o Codex Purpureus Rossanenensis no âmbito litúrgico, não só em relação ao lugar que o objeto ocupava, mas também ao significado de suas imagens. Podemos perceber isso nessa afirmação: "a natureza litúrgica das miniaturas prova indubitavelmente que o codex serviu para o uso na igreja e não para o uso privado" (MUÑOZ, 1907, p. 27). Não discordamos do caráter litúrgico vinculado ao manuscrito, nem de seu uso durante o ritual religioso (sinaxe) de caráter público. Contudo, esse raciocínio traz consequências consideráveis, antes de tudo, na percepção do conteúdo da fonte. A partir disso, a pergunta que fazemos é: as imagens com temas eucarísticos figuradas nestes fólios podem ser compreendidas apenas enquanto produto da retórica litúrgica e do culto eucarístico ou possuem implicações imperiais?

A historiografia da arte tradicional que se dedicou ao estudo do manuscrito atribuiu uma maior ênfase nas miniaturas, desconsiderando, muitas vezes, o texto

\footnotetext{
15 Disponível em :http://www.unesco.org/new/en/communication-andinformation/resources/multimedia/photo-galleries/preservation-of-documentary-heritage/photosmemory-of-the-world-register/2015/italy-the-codex-purpureus-rossanensis/ Acesso em: 07/03/2020.
} 


\section{artigos}

Implicações imperiais ligadas ao Codex Purpureus Rossanensis ( $\Sigma$ 042): Apontamentos a partir de uma análise imagética

que as acompanha. Pelo contrário, concordamos com Hye-Min Lee e Maud PérezSimon, que destacam a permeabilidade das fronteiras entre texto e imagem ao afirmarem que "as inscrições e as miniaturas são pensadas em conjunto, recebidas em conjunto e, portanto, são inseparáveis no processo interpretativo" (LEE; PÉREZSIMON, 2015, p. 293).

Com o intuito de facilitar a visualização entre texto e imagem, apresentaremos cada um dos três fólios em um esquema que garante a inteligibilidade das inscrições e sua tradução.

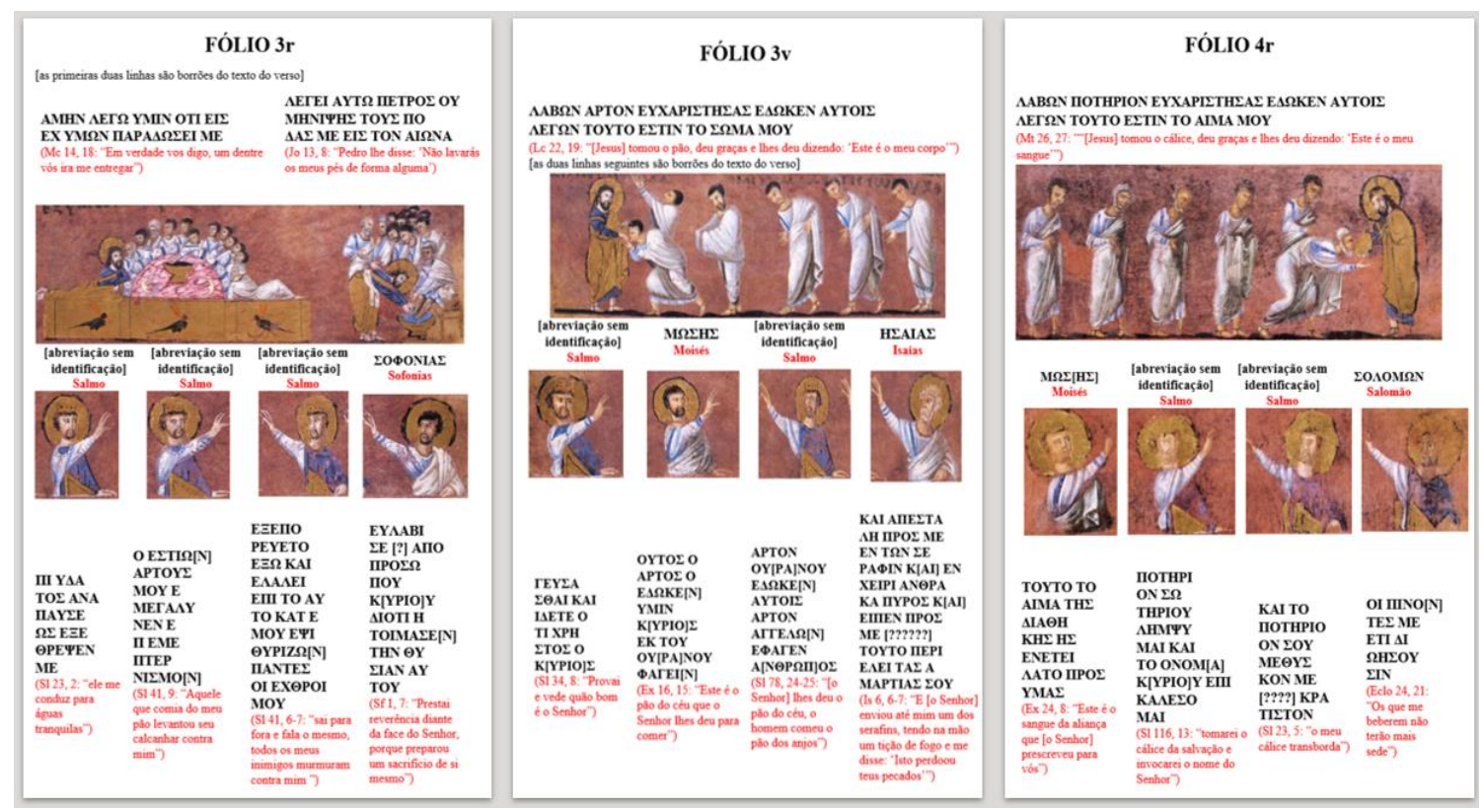

Figura 3: Esquema dos fólios 3r, 3v e 4r. Transcrição e tradução: Robson Della Torre. 


\section{artigos}

Karolina Santos da Rocha

As imagens possuem um posicionamento próprio no conjunto do manuscrito analisado. Elas se encontram figuradas, geralmente na metade superior da página, e na metade inferior há figuras de profetas ou personagens do Antigo Testamento que variam conforme o conteúdo iconográfico.

\section{FÓLIO $3 r$}

[as primeiras duas linhas são borrões do texto do verso]

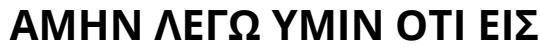
EX YM $\Omega N$ חAPA $\triangle \Omega \Sigma E I M E$

(Mc 14, 18: “Em verdade vos digo, um dentre vós ira me entregar")

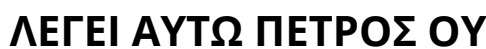

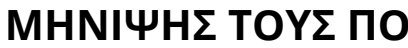

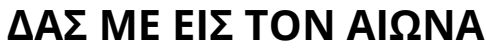

(Jo 13, 8: "Pedro Ihe disse: 'Não lavarás os meus pés de forma alguma')

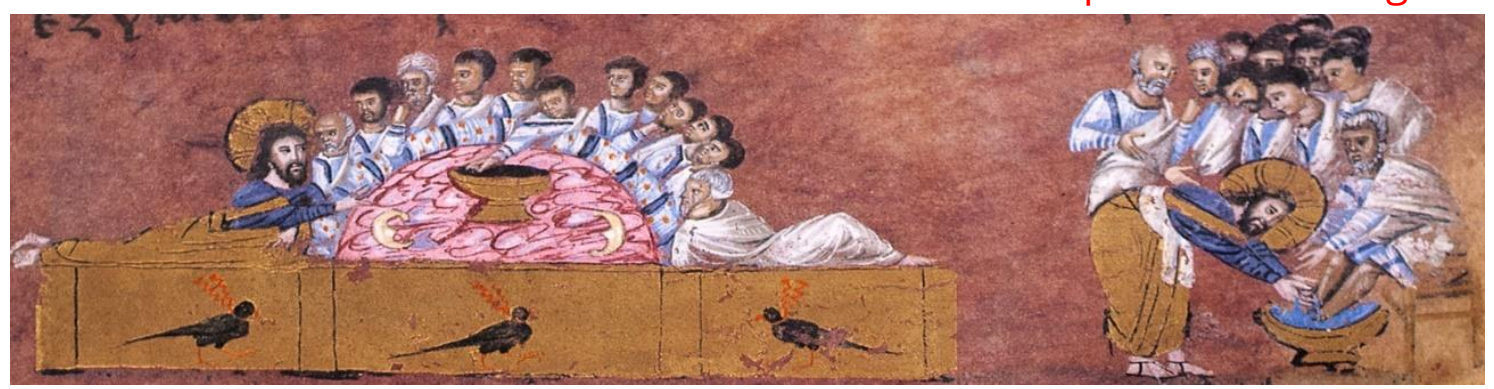

[abreviação [abreviação [abreviação sem identifica- sem identifica- sem identificação] ção]

Salmo Salmo

ção]

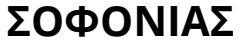
Sofonias Salmo 


\section{artigos}

Implicações imperiais ligadas ao Codex Purpureus Rossanensis ( $\Sigma$ 042):

Apontamentos a partir de uma análise imagética
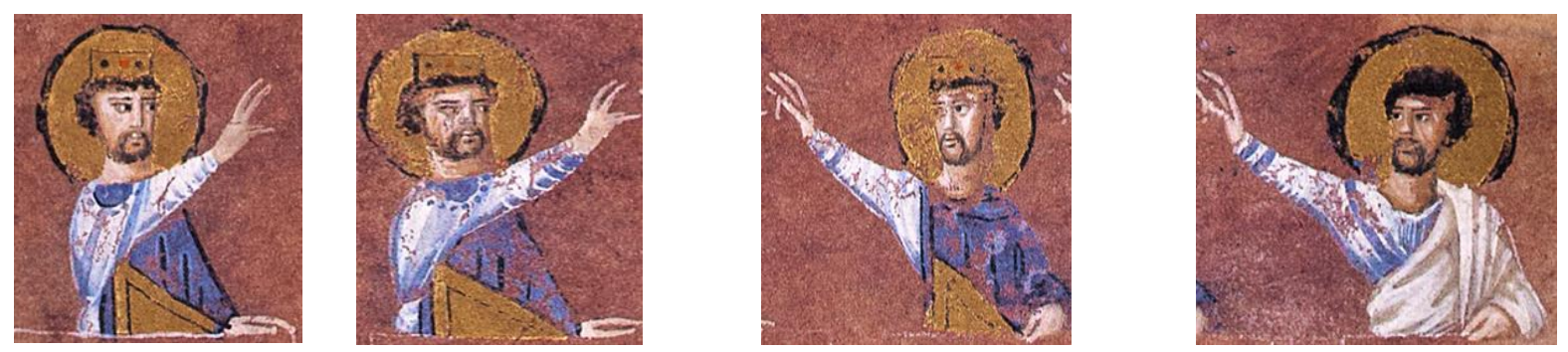

\begin{tabular}{|c|c|}
\hline EEEПO & EYAABI \\
\hline PEYETO & 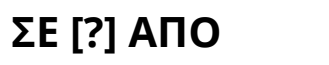 \\
\hline $\mathrm{E} \equiv \Omega \mathrm{KAl}$ & 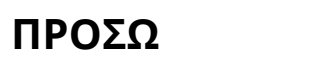 \\
\hline E^A^EI & חOY K[YPIO]Y \\
\hline EПI TO AY & $\Delta$ IOTI H \\
\hline TO KAT E & 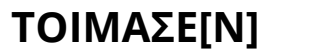 \\
\hline 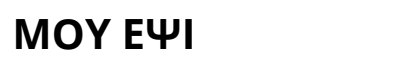 & THN OY \\
\hline OYPIZ $\Omega[N]$ & EIAN AY \\
\hline חANTE $\Sigma$ & TOY \\
\hline OI EXOPOI & (Sf 1, 7: “Prestai \\
\hline MOY & reverência diaı \\
\hline (SI 41, 6-7: "sai para & te da face do Se \\
\hline fora e fala o mes- & nhor, porque \\
\hline mo, todos os meus & preparou um \\
\hline $\begin{array}{l}\text { Inımıgos murmu- } \\
\text { ram contra mim ") }\end{array}$ & $\begin{array}{l}\text { sacrifício de si } \\
\text { mesmo") }\end{array}$ \\
\hline
\end{tabular}

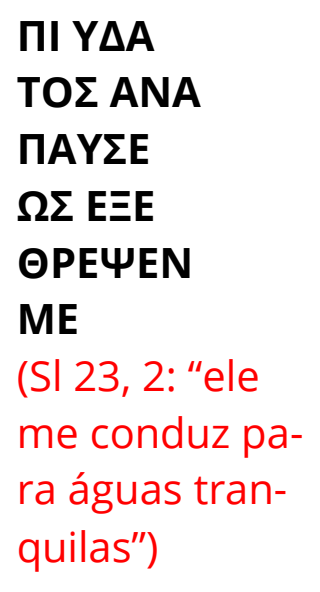

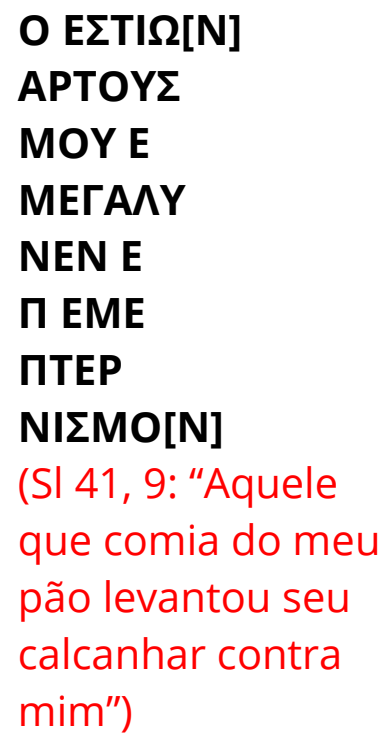

Figura 4: Esquema do fólio 3r. Esquema da autora. Transcrição e tradução: Robson Della Torre.

O primeiro fólio analisado e que, de certo modo, anuncia a distribuição do pão e do vinho nos fólios seguintes é a Última Ceia e o lava-pés no fólio 3r. As duas cenas são separadas, mas mostradas lado a lado; a Ceia (traição de Judas) à esquerda e o lava-pés à direita, ambas acompanhando passagens do Novo Testamento que se relacionam com as miniaturas. Além disso, na metade inferior do fólio, há o busto de quatro figuras identificadas como Davi (figurado três vezes) e Sofonias. Embaixo deles 


\section{artigos}

Karolina Santos da Rocha

há inscrições alinhadas em uma margem retangular. O busto de Davi acompanha os salmos e Sofonias acompanha uma passagem de sua profecia.

\section{FóLIO 3v}

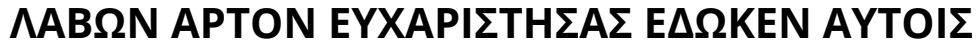

\section{$\Lambda$}

(LC 22, 19: “[Jesus] tomou o pão, deu graças e lhes deu dizendo: 'Este é o meu corpo"') [as duas linhas seguintes são borrões do texto do verso]

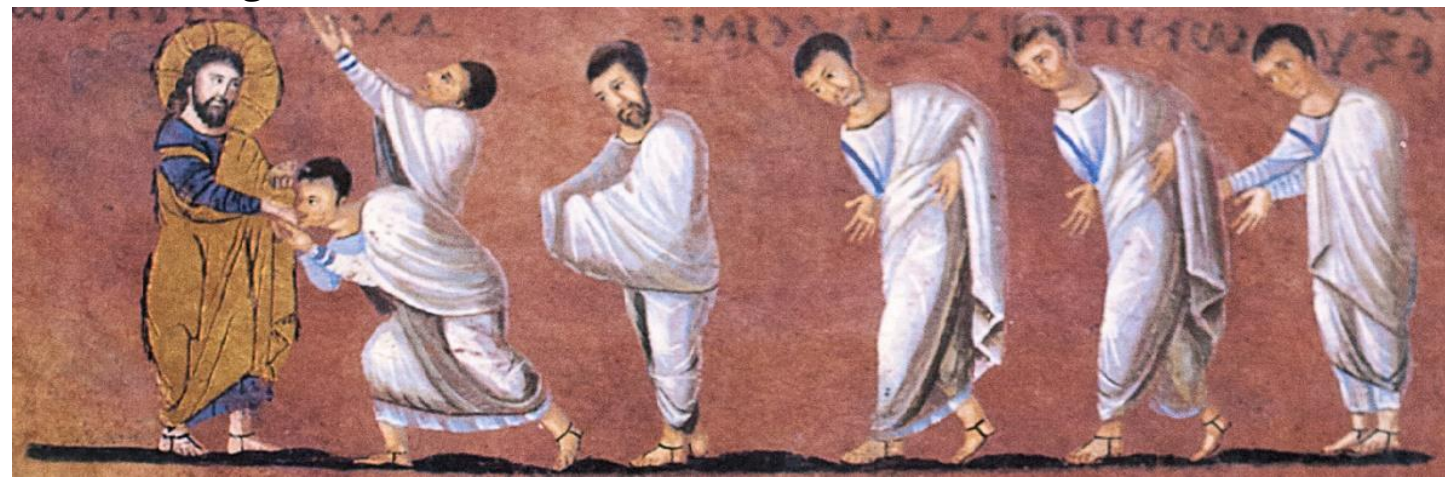

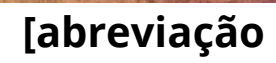
sem identificação] Salmo
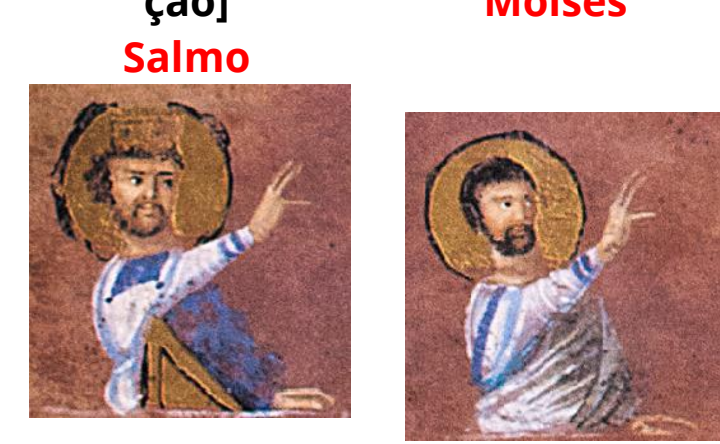

$\mathbf{M} \Omega \boldsymbol{\Sigma} \mathrm{H} \Sigma$ Moisés

TEY乏A

¿OAI KAI

IDETE O

TI XPH

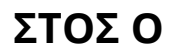
K[YPIO]乏

(SI 34, 8: "Provai

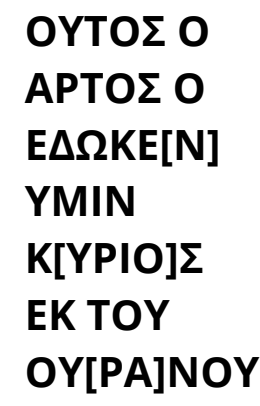

[abreviação sem identificação] Salmo

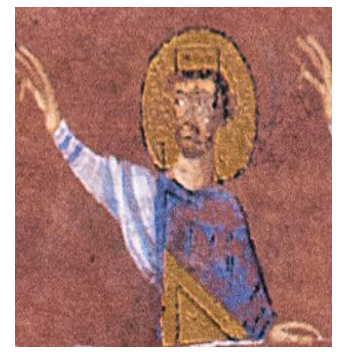

APTON OY[PA]NOY E $\Delta \Omega K E[N]$ AYTOIE APTON AГTE $\Omega[N]$ EФAГEN
HEAIA Isaías

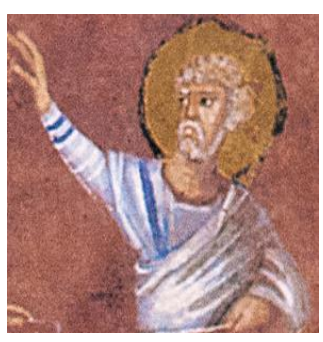

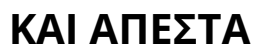

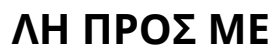
EN TSN $\Sigma E$ PAФIN K[AI] EN XEIPI ANOPA

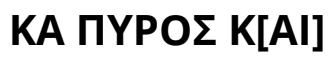

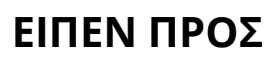




\section{artigos}

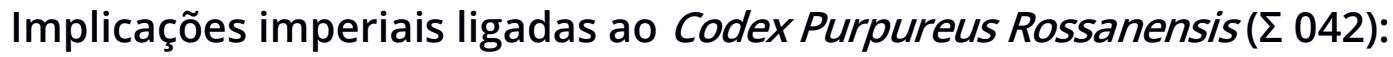

Apontamentos a partir de uma análise imagética

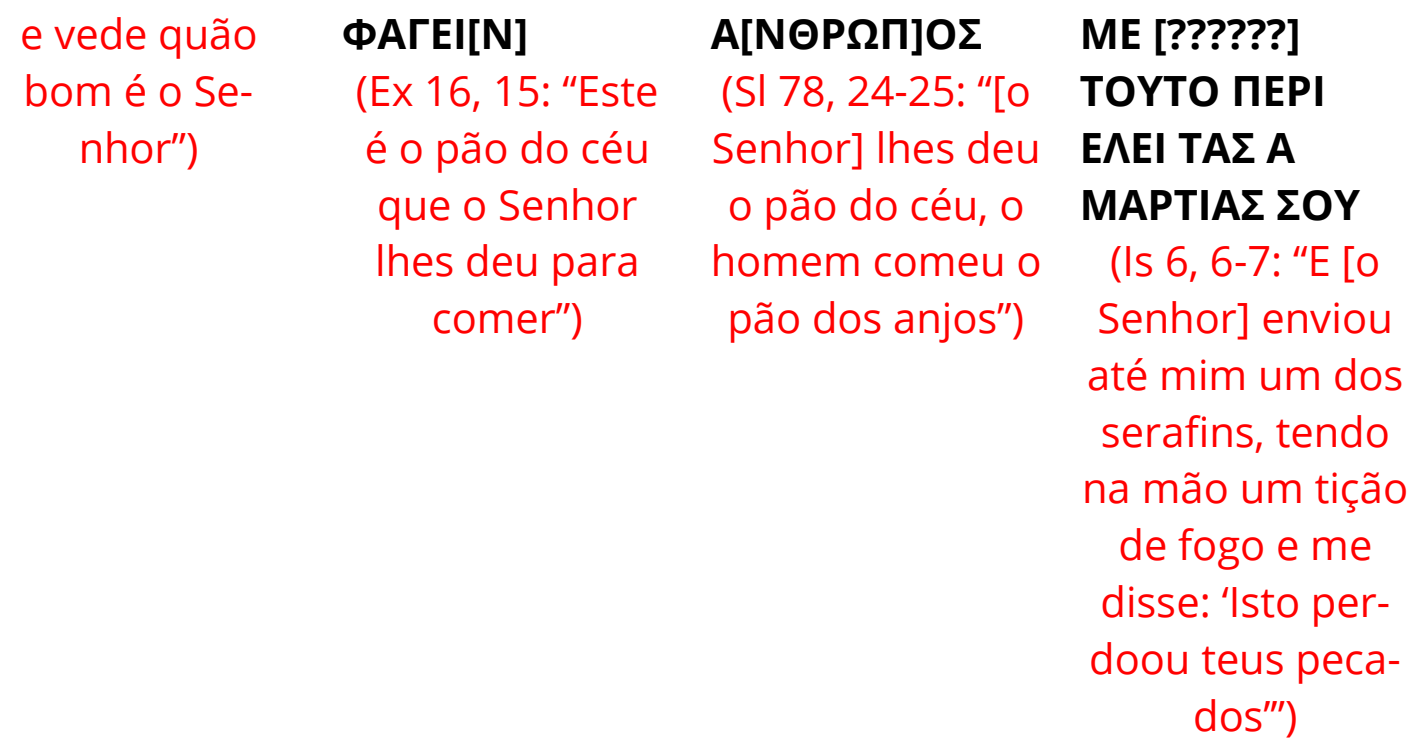

Figura 5: Esquema do fólio 3v. Esquema da autora. Transcrição e tradução: Robson Della Torre

Essa dinâmica está presente nos três fólios: Conforme o fólio 3v: a Distribuição do pão (corpo de Cristo) na metade superior (acompanhando uma passagem do Evangelho de Lucas) e na metade inferior do fólio há novamente quatro bustos identificados de modo sequencial como: Davi (que acompanha o Salmo), Moisés (uma passagem do Êxodo), novamente Davi (Salmo) e Isaías (Isaías).

\section{FÓLIO 4r}

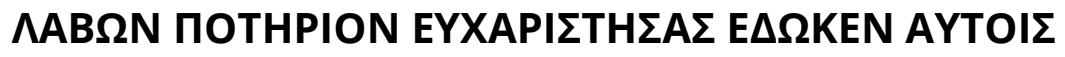

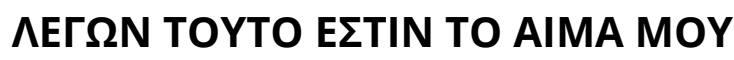

(Mt 26, 27: "'“'Jesus] tomou o cálice, deu graças e Ihes deu dizendo: 'Este é o meu sangue 


\section{artigos}

Karolina Santos da Rocha

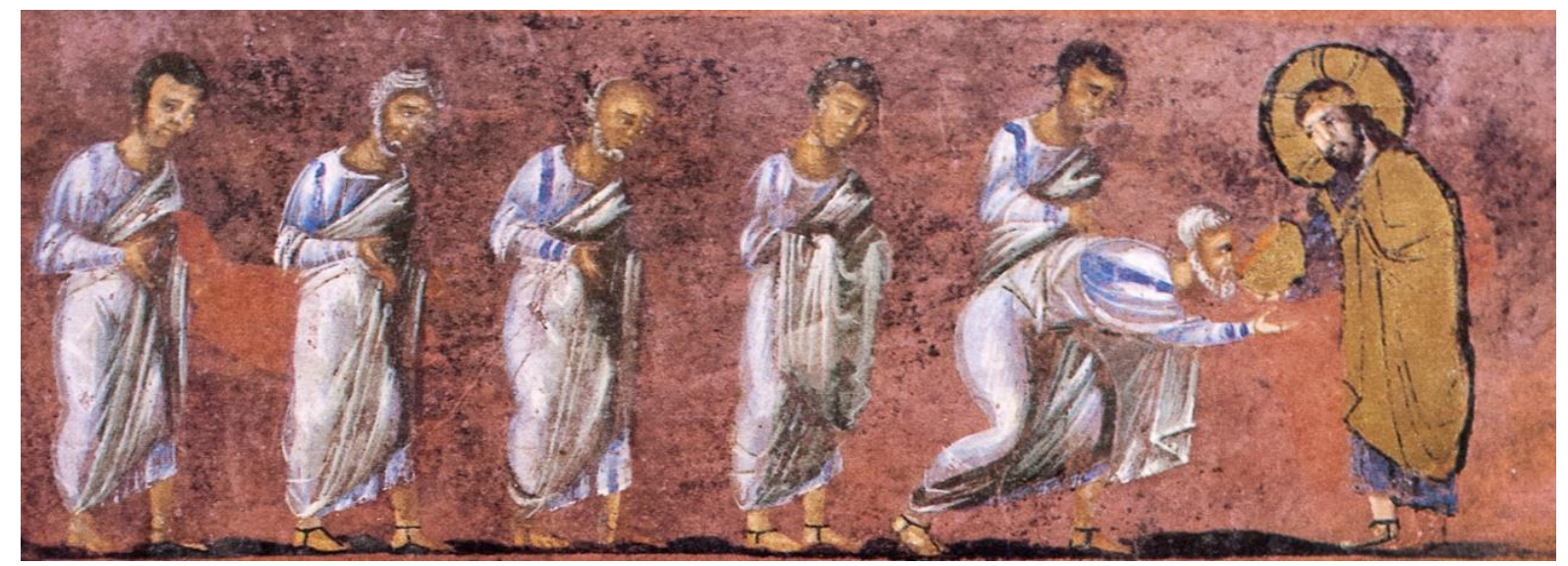

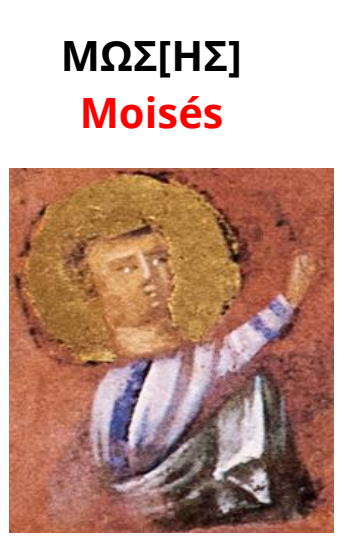
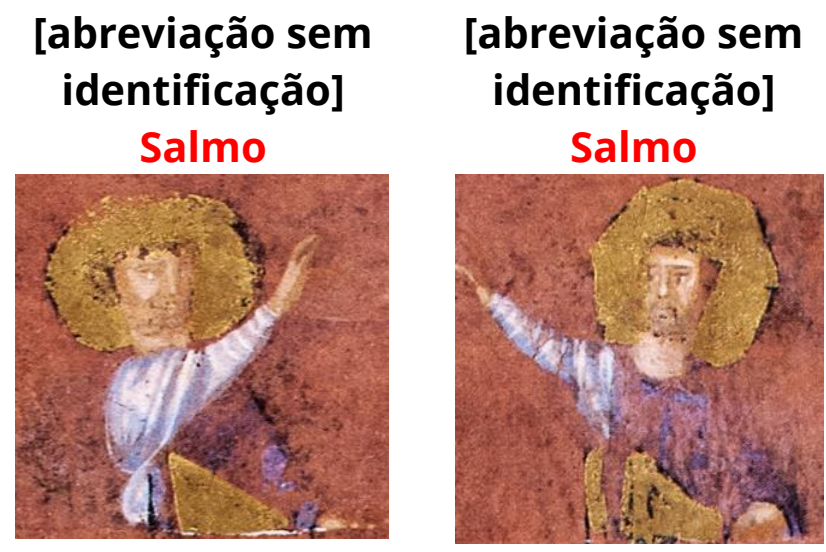

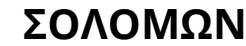 \\ Salomão}

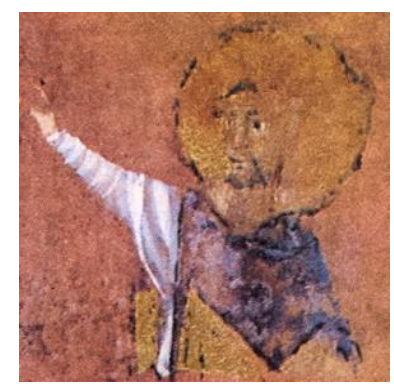

TOYTO TO

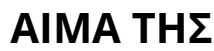

$\triangle \mathrm{IAOH}$

$\mathrm{KH} \boldsymbol{\Sigma} \mathrm{H} \boldsymbol{\Sigma}$

ENETEI

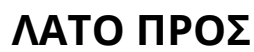

YMA $\Sigma$

(Ex 24, 8: “Este é o sangue da aliança que [o Senhor]

prescreveu para vós")
ПОTHPI

ON $\Sigma \Omega$

THPIOY

$\Lambda$

MAI KAI

TO ONOM[A]

K[YPIO]Y EחI

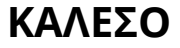

MAI

(SI 116, 13: "tomarei

o cálice da salvação

e invocarei o nome

do Senhor")

Figura 6: Esquema do fólio 4r. Esquema da autora. Transcrição e tradução: Robson Della Torre.

Em seguida, no fólio 4r: Cristo está à direita, com a taça na mão, oferecendo o vinho (sangue), e os apóstolos enfileirados e prontos para recebê-lo. Na metade 


\section{artigos}

\section{Implicações imperiais ligadas ao Codex Purpureus Rossanensis ( $\Sigma$ 042):} Apontamentos a partir de uma análise imagética

inferior do fólio, o busto de Moisés (acompanha o Êxodo), Davi (Salmo), Davi (Salmo) e Salomão (Eclesiástico).

Pensando nas relações entre texto e imagem, devemos levar em conta que "toda imagem amputa e amplifica ao mesmo tempo o texto que ela ilumina" (LEE; PÉREZSIMON, 2015, p. 295). Desse modo, acreditamos que as figurações da distribuição do pão e do vinho nos fólios $3 v$ e $4 r$ adicionam informações que não estão no texto bíblico ou nas citações dos evangelhos que encabeçam cada um dos fólios, pois aqui os apóstolos não estão apenas sentados à mesa conforme a tradição iconográfica da Última Ceia, mas avançam, como no ritual, para pegar o pão e vinho das mãos de Cristo, que está vestido como um sacerdote (apesar de sua túnica púrpura sugerir um outro tipo de poder: o imperial). Trata-se, portanto, de uma abordagem interpretativa, que, ao contrário do texto, concede uma maior ênfase na postura dos apóstolos diante de Cristo. ${ }^{16}$

Concentrar-nos-emos agora nas relações entre as figurações e inscrições do Antigo e Novo Testamento nestes fólios. Todas as passagens veterotestamentárias são "similares na estrutura dos acontecimentos" (AUERBACH, 1997, p. 27) com as passagens neotestamentárias escritas e figuradas na metade superior da página. Como exemplo, citamos a passagem do Êxodo que acompanha o busto de Moisés no

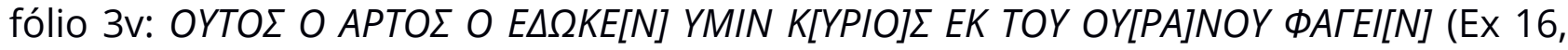

\footnotetext{
16 Percebemos que há diversas outras interpretações e inspirações identificadas nas imagens do codex. Conforme Muñoz (1907), a imagem do fólio 8r (apresentação de Cristo diante de Pilatos e a traição e morte de Judas) é claramente inspirada e interpretada por uma cena da corte imperial e ajustada a narrativa do Evangelho.
} 


\section{artigos}

\section{Karolina Santos da Rocha}

15: "Este é o pão do céu que o Senhor lhes deu para comer"). Este momento em que Moisés alimenta o povo no deserto com o maná (pão descido dos céus) é visto como uma prefiguração da Eucaristia.

Aqui, portanto, há uma clara e consistente relação entre o velho e o novo, o passado e o futuro, entre o Velho Testamento e o Novo Testamento. Trata-se de uma estrutura figurativa, conforme Auerbach, que investiga o uso do conceito de Figura pelos Pais da Igreja. Vale a pena ressaltar ainda que a Eucaristia é constantemente relacionada com a interpretação figural. Conforme Auerbach, “o próprio sacramento da Eucaristia é uma figura e dá-nos a mais pura imagem do aspecto concretamente presente, velado e provisório, assim como no aspecto eterno e supratemporal contido nas figuras" (AUERBACH, 1997, p. 51). Tal abordagem é influenciada por Tertuliano (século II/III) em sua obra Adversus Marcionem ${ }^{17}$, em que anuncia o significado do termo. ${ }^{18}$

Assim, embora cada elemento tenha o seu significado próprio, é apenas no interior dessa estrutura que ele ganha todo o seu sentido e exerce todas as suas possibilidades funcionais (FRANCO JR, 2008, p. 9). Nota-se isso a partir da própria disposição das imagens. Há personagens do velho testamento apontando ou direcionando o seu olhar para os acontecimentos do Novo Testamento na parte superior da página, de modo que há uma associação entre os dois planos e as duas temporalidades.

\footnotetext{
17 "Corpus illum suum fecit 'Hoc est corpus meum' dicendo, "id est, figura corporis mei". Figura autem non fuisset, nisi veritatis esset corpus." [Ele transformou-o em seu corpo, dizendo: "Este é meu corpo, isto é, a figura de meu corpo". Pois não teria havido figura se não houvesse um corpo de verdade.] (Tertuliano apud AUERBACH, 1997).

18 Contudo, tal caracterização da Eucaristia na perspectiva do Codex Purpureus Rossanensis pode ser problemática, pois há que se investigar ainda a recepção e alcance da obra de Tertuliano no Oriente.
} 


\section{artigos}

\section{Implicações imperiais ligadas ao Codex Purpureus Rossanensis ( $\Sigma$ 042):}

Apontamentos a partir de uma análise imagética

Uma outra questão importante é que, com o uso da estrutura figurativa, neste contexto e, principalmente, no período medieval, muitos monarcas eram comparados com governantes do Antigo Testamento e vistos como modelos ideais dignos de imitação (imitatio veritatis). Nos fólios apresentados, percebemos que todos os personagens figurados na metade inferior possuem linhagem régia ou eram de fato reis: Davi - rei de Israel, figurado inúmeras vezes e com a posse de atributos imperiais (coroa, trajes régios); Sofonias - tetraneto do rei Ezequias (sua genealogia é estabelecida em Sf 1,1); Isaías - identificado pela tradição judaica como detentor de linhagem real; Salomão - rei de Israel e filho de Davi; com exceção de Moisés que era um legislador (embora criado na corte de um Faraó), mas foi entendido como uma prefiguração do Cristo, sem contar que é uma figura usada constantemente para descrever atributos reais da realeza cristã por Eusébio de Cesaréia, por exemplo. Observemos ainda que, "O Antigo Testamento forneceu meios de reintegrar na legalidade cristã a realeza sagrada". (BLOCH, 1993, p. 75) Dessa forma, acreditamos que a presença destes personagens não se dá de forma neutra, mas possui intenções imperiais específicas.

Da mesma maneira, podemos destacar que os códices tingidos de púrpura eram associados à cultura imperial. Se, conforme Pastoreau (2015), toda cor é um atributo social, o purpúreo, neste contexto, é entendido como a cor digna de um monarca. A cor púrpura é um privilégio senatorial desde os tempos da República Romana e, como tal, acabou sendo associada ao poder imperial dos magistrados. Por consequência, foi adotada pelos imperadores, que determinaram sua exclusividade. Para além do simbolismo, destacamos ainda que tingir um pergaminho era algo extremamente 


\section{artigos}

\section{Karolina Santos da Rocha}

caro, que só um dignitário imperial ou membro da família imperial seria capaz de financiar, o que limitaria as possibilidades de confecção do códice ao círculo constantinopolitano. Dessa forma, a púrpura é um atributo de poder nesse contexto.

Courtney Booker (1997) afirma que os Evangelhos tingidos de púrpura começaram a se espalhar entre aristocratas e círculos religiosos durante o século IV ${ }^{19}$. Para ela, trata-se de uma resposta imperial a uma crise que ocorria com a aceitação do cristianismo e a disputa pela veneração de imagens imperiais, de modo que, "ao encomendarem suntuosos Evangelhos púrpuras e dourados, decoraram o único objeto permitido repousar sobre o altar (da igreja) com uma cor simbólica que sempre foi associada pelos cristãos às imagens imperiais" (BOOKER, 1997, p. 443). Isso demonstra a interpenetração da arte secular e religiosa, evidenciada por um Evangelho que não está dissociado das imagens imperiais. Há, pelo contrário, uma associação do poder imperial à autoridade de Cristo.

Na mesma linha de consideração, observamos que as figurações da distribuição do pão e do vinho nos fólios 3v e 4 r evocam o ritual da Proskynesis. Por muito tempo, a Proskynesis representou um dos termos mais importantes no vocabulário cerimonial

\footnotetext{
19 Autores como DINÇER (2019) defendem que, nesse contexto, os manuscritos púrpuras não eram considerados morais pelos pais da igreja, apresentando exemplos disso em Jerônimo e João Crisóstomo. No entanto, isso deve ser problematizado. Segundo Bischoff (1995), Jerônimo não gostava de códices purpúreos por acharem que possuíam elementos desnecessários e até enganosos. No prefácio ao seu comentário ao livro de Jó, ele reclamava, por exemplo, que as pessoas "preferem possuir os volumes bonitos do que os corretos" (magis pulchros habere malunt codices, quam emendatos). Aqui Emendatos significa, sobretudo, manuscritos com um texto muito preciso (fiel àquilo que teria sido o texto concebido originalmente pelos evangelistas), de preferência corrigido a partir de duas ou mais fontes para confirmar qual seria a versão mais "verdadeira" (exatamente como Jerônimo fazia). Ou seja, Jerônimo reclamava que as pessoas não se importavam que o texto que estavam lendo fosse uma falsificação grosseira, pois preferiam um livro ornamentado e com muitas imagens. Isso não indica, contudo, que Jerônimo se posicionasse contra os códices purpúreos em si, apenas a forma que o suporte se apresenta não o agradava.
} 


\section{artigos}

Implicações imperiais ligadas ao Codex Purpureus Rossanensis ( $\Sigma$ 042): Apontamentos a partir de uma análise imagética

da corte bizantina. Segundo Giorgio Agamben (2011), este ritual é frequente na época republicana romana como um gesto do suplicante que cai de joelhos diante do poderoso e que se difunde pouco a pouco como parte integrante do ritual imperial, que vem desde a época de Alexandre Magno. Os senadores e os cavaleiros de posição mais elevada beijavam o imperador na face (salutatio), mas, a partir do século IV a.C., só eram admitidos os beijos depois de se ajoelharem diante dele, até que, em Bizâncio, a salutatio acabou implicando sempre a adoratio: o beijo das mãos." (AGAMBEN, 2011, p. 114). Contudo, a proskynesis pode envolver também a mera reverência, curvando-se em direção à pessoa reverenciada (como, aliás, os três apóstolos à direita da imagem estão fazendo). Assim, mais do que ver na postura uma expressão da posição ocupada, devemos compreender que é a postura que leva de imediato ao efeito da hierarquia.

Ademais, a própria profecia de Sofonias anuncia a importância da proskynesis no contexto imagético analisado. Ele usa frequentemente o verbo reverenciar, e a palavra proskyneo aparece duas vezes antes da passagem apresentada no fólio $3 \mathrm{v}$.

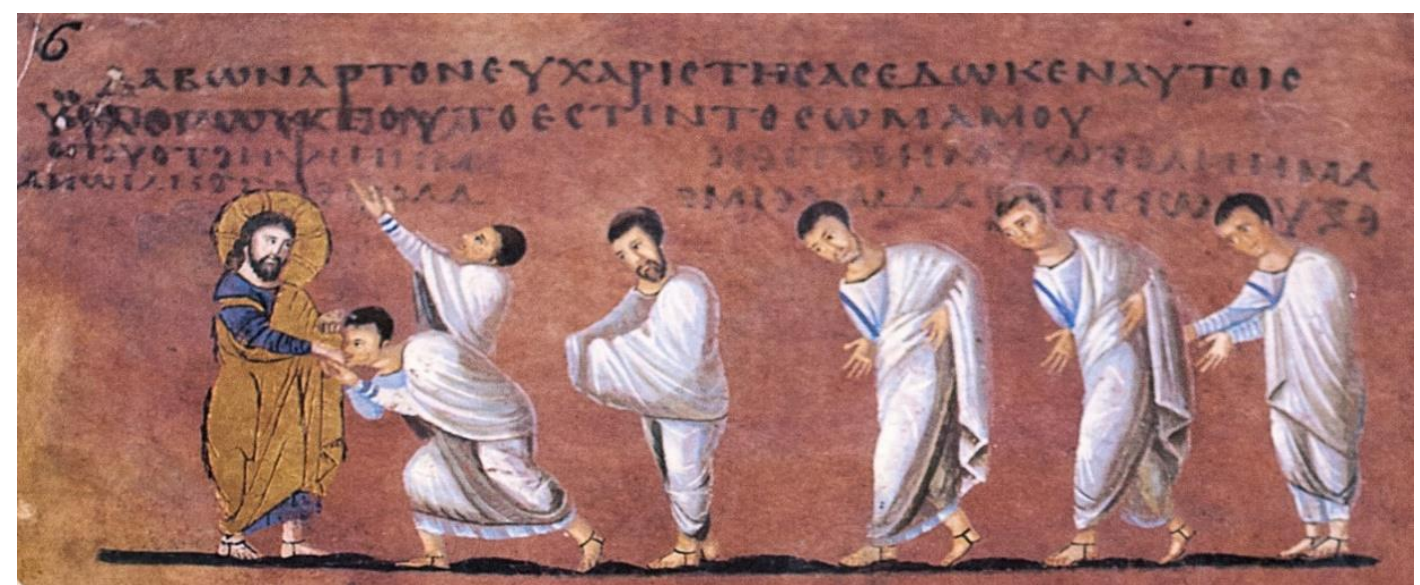

Figura 7: recorte do plano superior do fólio 3v. 


\section{artigos}

\section{Karolina Santos da Rocha}

Além disso, observou-se, frequentemente, que há fortes laços entre o cristianismo bizantino e o cerimonial imperial em Bizâncio. Aliás, é particularmente a partir do ritual da Proskynesis que paralelos são traçados entre o ritual bizantino cristão e o culto ao Imperador bizantino. (WARMIND, 1993, p. 211) E, não nos esqueçamos que a própria liturgia cristã, pelo seu elemento doxológico-aclamatório, não só a une ao mundo pagão, mas confere um caráter público, jurídico e político às celebrações. Isso ocorre, especialmente, durante a liturgia eucarística (AGAMBEN, 2011).

\section{Conclusão}

Desse modo, a resposta a nossa pergunta, feita no início deste artigo parece clara: As imagens com temas eucarísticos presentes no Codex Purpureus Rossanensis não expressam apenas o rito litúrgico encenado durante a sinaxe grega, mas possui implicações imperiais, na medida em que cada elemento está tão intimamente entrelaçado ao ponto de se tornarem indiscerníveis.

O quadro político-religioso demonstrado a partir dos argumentos que sustentam a análise imagética realizada neste artigo pode ser bastante profícuo para o entendimento do Codex Purpureus Rossanensis, seus modos de funcionamento e significados. Além disso, lembramos que a investigação de uma fonte imagética ultrapassa descrições iconográficas, ela se insere na estrutura social e se relaciona com o seu contexto de produção e manipulação, conforme demonstramos.

A fim de entender as imagens com temas eucarísticos contidas no manuscrito $\Sigma$ 042 é que construímos a nossa argumentação, o que nos conduziu, porém, a inúmeras outras formas de abordar uma fonte religiosa. Tal abordagem permitiu entender melhor o período histórico mencionado, bem como os atores históricos 


\section{artigos}

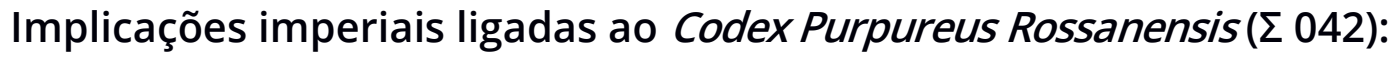

Apontamentos a partir de uma análise imagética

envolvidos. Não se trata, entretanto, de uma completa conclusão sobre o assunto, mas sim de uma abertura para a compreensão da documentação e de novas perspectivas de análise.

Elementos imperiais, embora sutis, são encontrados no Codex Rossanensis a partir da associação com elementos religiosos e litúrgicos. Assim, não há como descartar uma ou outra, ambas se complementam e "ampliam seu campo de intervenção e diversifica suas formas de ação, de tal forma que o assunto é de grande atualidade" (COUTROT, 2003, p. 335).

\section{Fontes}

Rossano, Codex $\Sigma$ 042, Museo Diocesano, s. n., séc. Vl.

Referências Bibliográficas

AGAMBEN, Giorgio. O Poder e a Glória. São Paulo: Boitempo, 2011.

AUERBACH, Erich. Figura. Trad. Duda Machado. São Paulo: Ática, 1997.

BASCHET, Jérôme; DITTMAR, Pierre Olivier (dir.). Les images dans l'Occident medieval. Turnhout: Brepols, 2015.

BATIFFOL, Pierre. L'Abbaye de Rossano: Contribution à l'histoire de la Vaticane. Paris: Alphonse Picard, 1891. 


\section{artigos}

Karolina Santos da Rocha

BEISSEL, Stephan. Vatikanische Miniaturen: Quellen zur Geschichte der Miniaturmalerei. Freiburg im Breisgau: Herder, 1891.

BELTING, Hans. An Image and Its Function in the Liturgy: The Man of Sorrows in Byzantium. Cambridge, MA, Dumbarton Oaks Papers, vol. 34/35, 1981.

BISCHOFF, Bernhard. Latin Palaeography: Antiquity and the Middle Ages. Translated by Dáibhi Ó Cróinín and David Ganz. Cambridge: Cambridge University Press, 1995.

BLOCH, Marc. A Realeza Sagrada nos Primeiros Séculos da Idade Média. In: Os Reis

Taumaturgos: O Caráter Sobrenatural do Poder Régio na França e Inglaterra. São Paulo: Companhia das Letras, 1993.

BÖHMER, Johann F. Regesta Imperii II. Sächsisches Haus: 919-1024. Dritte Abteilung:

Die Regesten des Kaiserreiches unter Otto III. Nach Johann Friedrich Böhmer neuarbeitet von Mathilde Uhlirz. Graz; Köln: Böhlau, 1956.

BOOKER, Courtney. The Codex Purpureus and its Role as an Imago Regis in Late Antiquity. In: DEROUX, Carl (ed.). Studies in Latin Literature and Roman History, Brussels: Latomus, 1997.

CAVALLO, Guglielmo. Codex Purpureus Rossanensis. Guide Illustrate. Roma: Salerno Editrice, 1992.

COUTROT, Aline. Religião e política. In: RÉMOND, René (org.). Por uma história política. Trad. Dora Rocha. $2^{\circ}$ edição. Rio de Janeiro: Editora FGV, 2003, p. 331-363. 


\section{artigos}

Implicações imperiais ligadas ao Codex Purpureus Rossanensis ( $\Sigma$ 042):

Apontamentos a partir de uma análise imagética

CRAWFORD, Matthew. Ammonius of Alexandria, Eusebius of Caesarea and the Origins of Gospels Scholarship. Cambridge, New Testament Studies, vol. 61, p. 1-29, 2015.

DINÇER, Pinar. Erken Bizans Dönemi Resimli Dini El Yazmaları. Istambul, ArtSanat, vol. 12, 2019.

ELLIOTT, James K. A Bibliography of Greek New Testament Manuscripts. Third edition, Leiden: Brill, 2015.

FRANCO JR., Hilário. Modelo e imagem: o pensamento analógico medieval. Auxerre, Bulletin du centre d'études médiévales d'Auxerre (BUCEMA), hors-série n. 2, 2008.

VON GEBHARDT, Oscar. Die Evangelien des Matthaeus und des Marcus aus dem Codex purpureus rossanensis. Leipzig: J. C. Hinrichs, 1883.

GRABAR, Andre, Christian Iconography: A Study of its Origins. Princeton: Princeton University Press, 1968.

GRADMANN, E. Die Wandgemälde in Sant'Angelo in Formis und die byzantinische Frage. Stuttgart, Christliches Kunstblatt für Kirche, Schule und Haus, vol. 15, p. 81 96, 1896.

HASELOFF, Arthur. Codex purpureus rossanensis: Die Miniaturen der griechischen Evangelien-Handschrift in Rossano. Berlin: Griesecke \& Devrient, 1898.

HIXSON, Elijah. Scribal Habits in Sixth-Century Greek Purple Codices. Leiden: Brill, 2019. 


\section{artigos}

Karolina Santos da Rocha

LEE, Hye Min; PÉREZ-SIMON, Maud. Relations texte/image. In: BASCHET, Jérôme; DITTMAR, Pierre Olivier (dir.). Les images dans l'Occident medieval. Turnhout: Brepols, 2015, p. 205-318.

LOERKE, William. The Rossano Gospels: The Miniatures. In: CAVALLO, Guglielmo (a cura di). Codex Purpureus Rossanensis: Commentarium, Roma: Salerno Editrice, 1987, p. 109-171.

MALPICA, Cesare. La Toscana, I'Umbria e la Magna Grecia. Napoli: Andrea Festa, 1846.

MANGO, Cyril. The Art of the Byzantine Empire, 312-1453: Sources and Documents. Toronto: University of Toronto Press, 1993.

MERCOGLIANO, Gennaro. L'imperatrice Teofano e il codex. Rossano: Ferrari Editore, 2016.

MUÑOZ, Antonio. Il codice purpureo di Rossano e il frammento sinopense. Roma: Danese editore, 1907.

PASTOREAU, Michel. La couleur. In: BASCHET, Jérôme; DITTMAR, Pierre Olivier (dir.). Les images dans l'Occident medieval. Turnhout: Brepols, 2015, p. 227-237.

RAPP, Claudia; KULZER, Andreas. (eds.). The Bible in Byzantium: Appropriation, Adaptation, Interpretation. Göttingen: Vandenhoeck \& Ruprecht, 2019 (Reading Scripture in Judaism and Christianity 25).

STUHLFAUTH, Georg. Die Engel in der altchristlichen Kunst. Freiburg; Leipzig: Mohr Siebeck, 1897. 


\section{artigos}

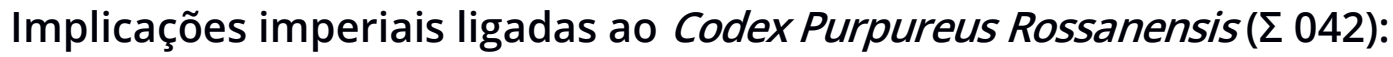

Apontamentos a partir de uma análise imagética

VOJVODIC, Dragan. On the Presentations of Proskynesis of the Byzantines Before Their Emperor. Ниш и Византија. Зборник радова, vol. 8, p. 259-270, 2010.

WARMIND, Morten. The cult of the Roman Emperor before and after Christianity. Åbo, Scripta Instituti Donneriani Aboensis, vol. 15, p. 211-220, 1993.

WEITZMANN, Kurt. Illustrations in Roll and Codex: A Study of the Origin and Method of Text Illustration. Princeton: Princeton University Press, 1947 (Studies in Manuscript Illumination 2).

Late Antique and Early Christian Book Illumination. London: Chatto and Windus, 1977.

Imagens

Figura 1: Esquema dos fólios construído por Arthur Haseloff, cf. (HASELOFF, 1898).

Figura 2: Respectivamente, fólios: 3r, 3v e 4r. Arcidiocesi di Rossano -Cariati (Unesco)

Figura 3: Esquema dos fólios 3r, 3v e 4r. Transcrição e tradução: Robson Della Torre.

Figura 4: Esquema do fólio 3r. Esquema da autora. Transcrição e tradução: Robson Della Torre.

Figura 5: Esquema do fólio 3v. Esquema da autora. Transcrição e tradução: Robson Della Torre. 


\section{artigos}

Karolina Santos da Rocha

Figura 6: Esquema do fólio 4r. Esquema da autora. Transcrição e tradução: Robson Della Torre.

Figura 7: Recorte do plano superior do Fólio 3v. 